\title{
USO VARIADO DE [aI] E [a] NA FALA FLORIANOPOLITANA - UMA ANÁLISE A PARTIR DA FONOLOGIA DE USO
}

\author{
VARIED USE OF [aI] AND [a] IN FLORIANOPOLITANA SPEECH - AN ANALYSIS \\ FROM THE PHONOLOGY OF USE
}

\section{Carine Haupt}

Universidade Federal do Tocantins

carineh@uft.edu.br

RESUMO: Neste trabalho, apresentamos um estudo sobre a monotongação do ditongo [aI] em sílabas abertas e fechadas na fala dos florianopolitanos a partir das entrevistas do banco de dados do VARSUL (Variação Linguística na Região Sul do Brasil). Baseados na Fonologia de Uso e na Teoria de Exemplares, analisamos quantitativamente as ocorrências de monotongação, com o objetivo de verificar os efeitos da frequência de uso no fenômeno. A análise dos dados nos leva a assumir que o fenômeno de monotongação é um fenômeno de variação, salvo os contextos de consoante seguinte palato-alveolar (em sílabas abertas), nos quais a monotongação é quase categórica. Para as sílabas fechadas, temos a influência da palatalização da fricativa final como determinante para o apagamento da semivogal. $\mathrm{O}$ fenômeno de variação não se dá de forma abrupta e, através da análise acústica, analisamos a gradiência da monotongação. Observamos que a semivogal deixa vestígios de sua presença: na duração do segmento resultante da monotongação e na trajetória dos formantes, em que pudemos identificar diferentes configurações, tais como o primeiro alvo (vogal de base) alongado ou a articulação de um segundo alvo (semivogal) que não se completa. Ademais, constatamos que, mesmo em ditongos, nem sempre é possível identificar dois alvos estáveis, fato que nos leva a considerar que a gradiência do fenômeno já se inicia nos segmentos que ainda percebemos como ditongos.

PALAVRAS-CHAVE: Monotongação; Fonologia de Uso; Exemplares; Gradiência

ABSTRACT: This work presents a study on the monophthongization of the diphthong [aI] within open and closed syllables in the speech of native speakers from Florianópolis as detected in interviews contained in VARSUL (Variação Linguística na Região Sul do Brasil [Urban Linguistic Variation in Southern Brazil]). Based on a Used-Based Model for Phonology and the Exemplar Theory, we analyze quantitatively the occurrence of monophthongization, in order to assess the effects of frequency of use on the phenomenon. In addition, we assume that the phenomenon of monophthongization is a case of variation, except in contexts in which the diphthong is followed by a alveopalatal consonant (in open syllables), in which monophthongization is almost categorical. For closed syllables, the palatalization of the final fricative is a major influence in the erasing of the semivowel. The phenomenon of variation does not occur categorically, and, through acoustic analysis of some interviews, we analyzed the gradience of the monophthongization. We observed that the semivowel leaves features 
of their presence: in the length of the segment resulting from monophthongization; and in the trajectory of formants, that we could identify different settings, such as a longer first target or an articulation of a second target that is not complete. Moreover, we note that even in diphthongs, is not always possible to identify two stable targets, a fact that leads us to believe that the gradience of the phenomenon starts already in the segments that we still perceive as diphthongs.

KEYWORDS: Monophthongization; Used-Based Model for Phonology; Exemplars; Gradience

\section{INTRODUÇÃO}

Neste artigo, apresentamos um estudo sobre a alternância do uso do ditongo [aI ] e do monotongo [a], como fenômeno de variação na fala da cidade de Florianópolis. Para análise quantitativa foram usados os dados do VARSUL (Variação Linguística da Região Sul). A discussão dos resultados será pautada na teoria da Fonologia de Uso e da Teoria dos Exemplares. O objetivo, portanto, é apresentar um novo olhar sobre um fenômeno já vastamente estudado. Considerando as teorias propostas para esse novo olhar, serão discutidos os efeitos de frequência, os contextos alternativos e a gradiência fonética do fenômeno, pontos esclarecidos na seção 2.

É importante lembrar que, embora tenhamos tomado um corpus construído a partir dos preceitos da sociolinguística, não analisamos variáveis sociais e tampouco variáveis linguísticas isoladas. Consideramos a palavra como lócus de análise e, como consequência, as variáveis linguísticas estarão atreladas à frequência dos itens lexicais, e serão avaliadas considerando esse fato. Para apresentar a análise, dividimos o texto em três partes. Na primeira, apresentamos uma breve revisão da teoria que norteia esse trabalho, juntamente com as hipóteses. Na segunda, mostramos os dados quantitativos, analisando os efeitos de frequência no fenômeno. Analisamos primeiramente os ditongos em sílabas abertas, como em caixa e, em seguida, os ditongos em sílabas fechados, como em mais. Na terceira parte, analisamos a gradiência, discutindo dois parâmetros: a duração e a formação formântica. Utilizamos o software Praat para tal análise.

Usamos também o apoio da estatística para referendar as nossas conclusões. A significância entre a frequência de ocorrência e a monotongação foi medida pelo teste qui-quadrado. Na análise acústica, nos valemos dos testes Anova e de Tukey. O Anova indica o tamanho da diferença entre diferentes grupos, em função do tamanho da variação dentro de cada grupo. O objetivo, portanto, é testar a significância entre as diferenças de duração dos diferentes segmentos analisados. Como o ANOVA não nos informa qual das médias é a diferente, efetuamos um teste de comparação múltipla, o teste de Tukey, que nos informa entre quais grupos houve significância. O mesmo procedimento foi utilizado ao compararmos os valores dos formantes (F1 e F2) da vogal e da semivogal do ditongo em estudo.

\section{A FONOLOGIA DE USO E TEORIA DOS EXEMPLARES}

De acordo com Bybee (2000), o uso afeta as representações mentais. Assim, palavras e construções mais frequentes são mais fortes no sentido de que são mais 
facilmente acessadas, enquanto as menos frequentes tornam-se mais fracas, podendo até ser esquecidas. A força lexical de uma palavra pode mudar à medida que é mais ou menos usada em diferentes contextos. Outros autores, como Ellis (2002) que tratam de teorias cognitivas e psicolinguísticas de aquisição, também atestam a importância da frequência, na medida em que argumentam que todas as unidades linguísticas são abstraídas do uso da língua. Nessa perspectiva, a aquisição da gramática é uma aprendizagem gradual de milhares de construções e da abstração a partir da frequência de suas regularidades. Assim, a frequência é a chave determinante da aquisição, porque as regras da língua, em todos os níveis, são regularidades estruturais que emergem da análise das características distribucionais do input da língua.

No que tange à Fonologia de Uso e às variações e mudanças sonoras, temos duas categorias de frequência: a frequência de ocorrência e a frequência tipo. A primeira refere-se à ocorrência de determinado item lexical em um corpus, enquanto a última refere-se a um padrão na língua. Em relação à frequência de ocorrência, temos de considerar que ela pode exercer diferentes efeitos, dependendo das características do fenômeno. Segundo Phillips (1984), há mudanças que afetam primeiramente as palavras mais frequentes e outras que afetam primeiramente as menos frequentes. De acordo com essa autora, as mudanças foneticamente motivadas, ou seja, que têm base na fisiologia da fala, atingem, em primeiro lugar, as palavras mais frequentes, efeito devido à automatização dos gestos articulatórios (BYBEE, 2000, 2001). Entre esses fenômenos, encontram-se os casos de redução, apagamento e assimilação. Mudanças que afetam primeiramente as palavras menos frequentes, por sua vez, são aquelas decorrentes de casos de analogia ou de casos que requerem análise, seja ela sintática, morfológica ou fonológica. Em Phillips $(1984,2001)$ encontramos vários casos em que a reanálise ocorre primeiramente nas palavras menos frequentes. Citamos o exemplo do apagamento do glide, no inglês, no qual ocorreu uma mudança nas restrições fonotáticas que foi além de uma mudança na superfície fonética (PHILLIPS, 1984). De acordo com a autora, não havia contexto fonético propício para esse apagamento. Ele ocorreu em sílabas iniciais tônicas, em que se espera um fortalecimento, e não era resultado de uma assimilação. O levantamento feito pela autora confirma sua hipótese: as palavras menos frequentes mudaram primeiro nesse caso.

Bybee (2003) apresenta ainda outro efeito da frequência. Segundo ela, os itens frequentes, paradoxalmente, desencadeiam mudanças e, ao mesmo tempo, preservam formas. Bybee (2003) afirma que as mudanças costumam ser de forma e de significado, enquanto a preservação se dá em nível morfossintático. Seriam os efeitos de processamento que resultam na automatização da fala versus os efeitos de armazenamento. Assim, estruturas morfológicas de palavras e propriedades sintáticas de construções, quando muito frequentes, passam a se fortalecer e são preservadas. Um bom exemplo disso são algumas formas irregulares de verbos muito frequentes, como o verbo ser.

Em se tratando de monotongação, nosso objeto de estudo, temos um caso de redução, uma variação de superfície fonética. Assim, lançamos a hipótese de que as palavras mais frequentes são atingidas com mais intensidade, uma vez que se trata de um fenômeno com motivação fisiológica, conforme Phillips (1984). Os estudos variacionistas a respeito da monotongação confirmam a motivação fonética no fenômeno, uma vez que os contextos favorecedores são aqueles em que os ditongos são seguidos de consoante fricativa alveopalatal ou de tepe. No entanto, esses mesmos estudos atestam a ocorrência de monotongação em outros contextos, em palavras como 
maior e vai. Esses casos de monotongação não são em número expressivo, e esses contextos acabam sendo classificados como não favorecedores, uma vez que, em termos estatísticos, a probabilidade de ocorrer a monotongação é muito baixa. No entanto, em nossa discussão, serão considerados e explicados juntamente com os contextos tidos como favorecedores nos estudos sociolinguísticos.

Além da frequência de ocorrência, como já mencionado, temos também a frequência tipo. A frequência tipo é a frequência de um padrão no léxico, refere-se à frequência de dicionário, como um afixo ou desinência. No português, por exemplo, podemos formar o plural de nomes com diferentes desinências $(-s$, -is, -eis, entre outras), no entanto, a frequência tipo de $-\mathrm{s}$ é maior em relação às outras, porque se aplica a um número maior de palavras. A frequência tipo, portanto, determina a produtividade de padrões fonológicos, morfológicos e sintáticos, porque quanto maior o número de itens para uma determinada categoria, mais gerais serão seus traços e mais facilmente se estenderão a outros itens, promovendo, assim, generalizações.

Resumidamente, podemos dizer que a alta frequência tipo garante que uma determinada construção seja usada frequentemente, fortificando seu esquema representacional, tornando-a mais acessível para o uso em novos itens. Já a frequência de ocorrência promove o fortalecimento e conservação de formas irregulares e idiomáticas, que só poderiam sobreviver por causa de sua alta frequência (Bybee, 2003), e as mudanças fonéticas e semânticas, atingindo primeiramente palavras muito frequentes, quando foneticamente motivadas, e as menos frequentes (Phillips, 1984) quando tiverem outras motivações, que não fisiológicas. No caso do fenômeno da monotongação, analisamos os efeitos da frequência de ocorrência, como já mencionado acima, a fim de testar a hipótese de que as palavras mais frequentes monotongam em maiores proporções, uma vez que se trata de um fenômeno com motivação fonética. Em relação à frequência tipo, consideramos que ela está relacionada aos padrões relativos aos fatores estruturais citados nos estudos variacionistas - tonicidade, posição da sílaba em que se encontra o ditongo, extensão do vocábulo, status morfológico, contexto fonético seguinte - e será mencionada quando nos referirmos a esses fatores.

Bybee (2002) discute, ainda, a questão dos contextos alternativos e uniformes quando trata dos efeitos da frequência de ocorrência dos morfemas na mudança/variação nas palavras. Os contextos uniformes são aqueles que sempre estão presentes em cada palavra e, portanto, encontram-se no interior da mesma. Já os contextos alternativos são aqueles que podem ou não estar presentes na palavra e podem ser internos ou externos à mesma. Como contextos uniformes, temos, para a monotongação, a fricativa palato-alveolar nas sílabas fechadas. Os contextos alternativos são as diversas possibilidades de contexto seguinte ao ditongo. Os contextos alternativos externos à palavra serão os contextos que iniciam a palavra seguinte e serão importantes para a discussão da monotongação em sílabas fechadas, já que esses ditongos encontram-se sempre na última sílaba, e em alguns ditongos em sílabas abertas, em formas como vai, por exemplo. Consideramos, como hipótese inicial, que os contextos alternativos favorecedores sejam os mesmos que os contextos uniformes, internos à palavra, ou seja, a fricativa palato-alveolar.

Mencionamos, também, no decorrer da exposição, termos como exemplares e nuvens de exemplares. Essas expressões referem-se ao modelo representacional condizente com a Fonologia de Uso, a Teoria dos Exemplares. Segundo Johnson (1997), em um modelo de exemplares, todas as amostras percebidas são armazenadas e 
categorizadas, criando, assim, categorias que representam as variações encontradas no uso e no processamento da língua. Esse autor afirma também que não somente os detalhes fonéticos são armazenados, mas também outras informações, como a voz do interlocutor, os significados e os contextos de uso. Assim, todas as variantes fonéticas estão alocadas na memória. De acordo com Pierrehumbert (2000), essas variantes são organizadas em clusters, ou seja, em nuvens de exemplares. Uma nuvem, então, é a reunião de exemplares com mais similaridade do que outros. Essas nuvens de exemplares não são fixas, elas vão mudando de acordo com a experiência, com o uso da língua. Exemplares mais frequentes, quando dentro de uma nuvem, tornam-se mais fortes, e os menos frequentes, com o tempo, deixam de ser usados. Dessa forma, a taxa de variação fonética de uma palavra pode mudar gradualmente com o tempo, a partir das experiências dos falantes com a língua.

A categorização, nesse modelo, é baseada no critério de similaridade fonética. Langacker (2000) diz que a categorização pode ser entendida como uma espécie de comparação. Uma forma no input será comparada com as unidades linguísticas já armazenadas e será classificada como pertencente àquela categoria com que tiver mais propriedades similares. Bybee (2001) discute como podemos delimitar uma categoria, isto é, o quanto de similaridade é necessário para que dois segmentos sejam da mesma categoria. Como resposta, a autora diz que "a rough answer may be that allophonic differences at the level at which linguists note and describe them are distinct enough to constitute separate categories" (Bybee, 2001, p.53). Assim, podemos considerar um ditongo e um monotongo como duas categorias distintas. No entanto, considerando que a variação entre elas é gradual, outras categorias podem ser encontradas entre um ditongo e um monotongo.

Para averiguar essas categorias intermediárias e tendo em vista que um dos pressupostos da Fonologia de Uso é de que a mudança se instala de forma gradativa, tanto lexical quanto foneticamente, partimos para outra etapa de nosso estudo: a análise da gradiência fonética do fenômeno. Para o fenômeno da monotongação do ditongo [aI ], lançamos a hipótese de que a gradiência pode se manifestar na duração dos segmentos ou em indícios da semivogal nos formantes. Assim, esperamos que o segmento resultante da monotongação seja mais longo do que de uma vogal simples. Detalhes sobre os procedimentos dessa análise são apresentados na seção 4, que trata da gradiência do fenômeno, identificada a partir de análises acústicas.

\section{USO VARIADO DO DITONGO [ar] E DO MONOTONGO [a]}

O ditongo [aI] teve um total de 2.662 ocorrências no corpus analisado, das quais 679 monotongaram, o que corresponde a aproximadamente $25 \%$. Primeiramente, apresentamos, na Tabela 1, os totais de ditongos preservados e monotongados para o ditongo [aI] em sílabas abertas e em sílabas fechadas. 
Tabela 1: Ocorrências de monotongação do ditongo [ar] em sílabas abertas e fechadas

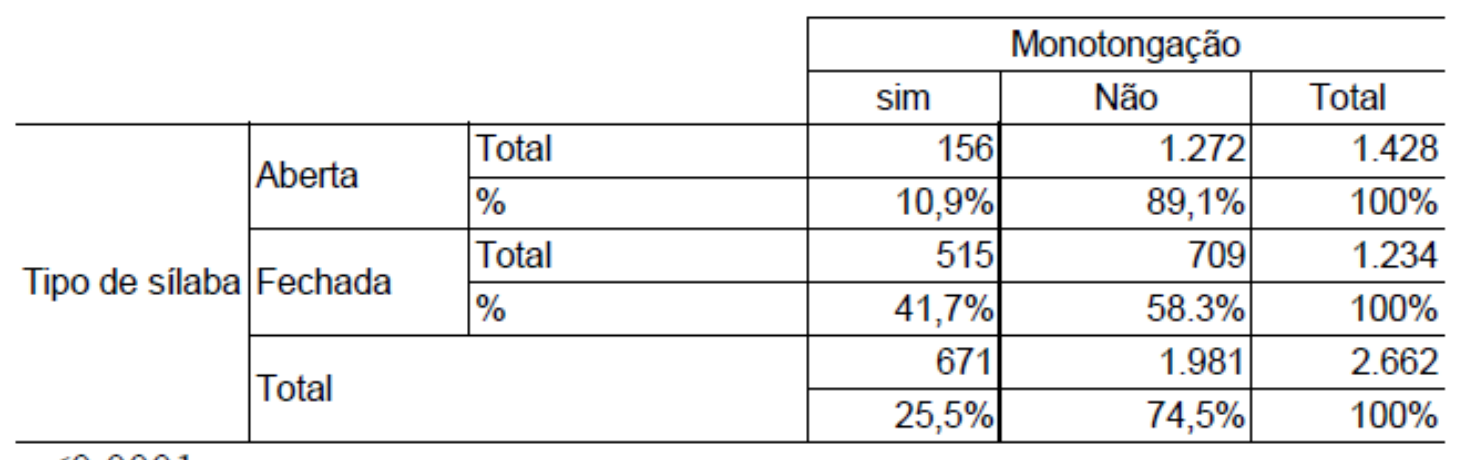

$\mathrm{p}<0,0001$

Observamos que houve um maior número de monotongações nas sílabas fechadas (515 contra 164 nas abertas). O teste qui-quadrado confirma essa relação, de modo que podemos assumir que a influência desse fator estrutural é significativa. $O$ fato de termos encontrado monotongações em sílabas fechadas corrobora os resultados de Brescancini (2009). Em relação às sílabas abertas, as monotongações concentram-se nas palavras cujo ditongo é seguido de fricativa palato-alveolar.

Temos, então, casos bem específicos em que ocorre a monotongação no ditongo [ar]: i) em sílabas abertas, predominantemente seguidas de consoante palato-alveolar, contexto propício para o fenômeno, portanto, com motivação fonética, como em

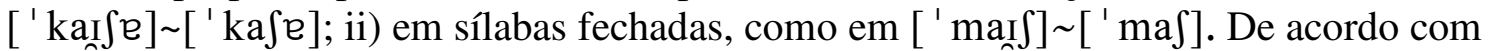
as nossas hipóteses, o fenômeno foneticamente motivado atinge em maiores proporções as palavras com frequência de ocorrência mais alta. Na Tabela 2, distribuímos as palavras com ditongo [ar] em sílabas abertas (as sílabas fechadas são analisadas mais a frente) em três grupos de acordo com a frequência de ocorrência no corpus utilizado ${ }^{1}$.

\footnotetext{
1 Alta frequência: palavras com até $1 \%$ de ocorrência em relação ao total de itens com ditongo; frequência moderada: palavras entre $1 \%$ e $0,1 \%$ do total de itens lexicais com ditongo; baixa frequência: palavras com menos de $0,1 \%$ de ocorrência.
} 
Tabela 2: Monotongações do ditongo [aI] em sílabas abertas distribuídas de acordo com a frequência de ocorrência

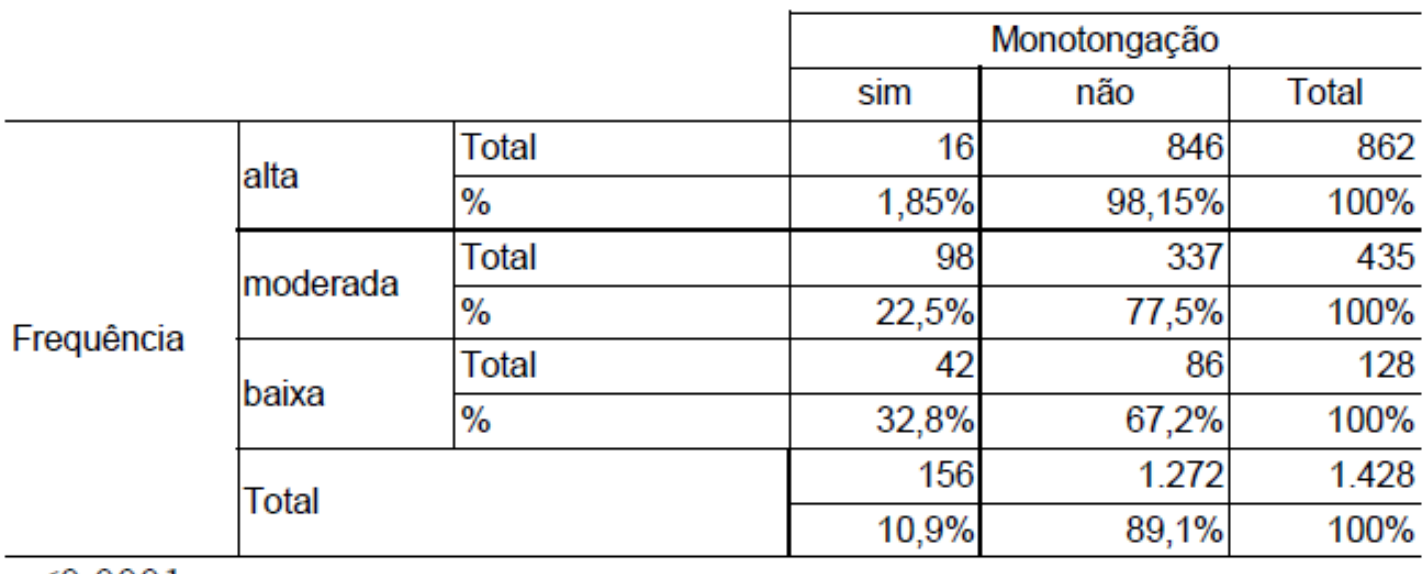

$\mathrm{p}<0,0001$

Vemos que a relação entre as variáveis frequência e monotongação não é aquela que esperávamos: as palavras mais frequentes monotongaram menos. As monotongações ocorreram em maior concentração nas palavras com frequência de ocorrência baixa, seguidas daquelas com frequência moderada. Esse fato se explica por dois motivos. O primeiro refere-se à monotongação dos ditongos seguidos de consoante fricativa palato-alveolar, decorrente de uma assimilação. As monotongações nesse contexto ocorrem tanto em palavras com frequência de ocorrência moderada, quanto naquelas com baixa frequência (com frequência de ocorrência alta não houve nenhum item) em percentuais de quase $100 \%$. Esse fato nos permite afirmar que a automatização, nesse contexto fonético propício, reduz o ditongo [aI] a um monotongo, fortificando muito as nuvens de exemplares com palavras com essa categoria em detrimento das mesmas com ditongo. $\mathrm{O}$ ditongo praticamente não existe mais na fala nesse contexto, continua, no entanto, no registro escrito, o que pode influenciar a manutenção do ditongo nos casos remanescentes.

A segunda razão diz respeito à alta frequência de ocorrência dos itens lexicais vai, pai e praia. A palavra praia teve 131 ocorrências e nenhuma monotongação. $\mathrm{O}$ ditongo se encontra em sílaba tônica, seguido de vogal, contexto em que a redução não é esperada, especialmente pelo fato do apagamento da semivogal resultar em duas vogais contíguas. No entanto, também em contexto vocálico, tivemos monotongações na palavra maior (3 monotongações, equivalente a 7,1\% das ocorrências), que, por sua vez, teve frequência moderada. É possível que o fato de ela se encontrar em sílaba átona propicie condições para a redução, o que não ocorre com a palavra praia.

Nos monossílabos supracitados também encontramos alguns casos de monotongação. A palavra pai teve apenas 1 monotongação em 306 ocorrências $(0,32 \%)$ e a forma verbal vai, 15 monotongações em 425 ocorrências (3,5\%). Considerando que pai é uma palavra com altíssima frequência de ocorrência (a segunda palavra mais frequente com ditongo [a $\mathrm{a}_{\mathrm{r}}$ ] em sílabas abertas), podemos concluir que elaé uma palavra com alta autonomia lexical, e, por isso, independentemente do contexto alternativo, o ditongo será preservado. 
A mesma autonomia lexical seria esperada da palavra vai, já que é o item mais frequente com ditongo [ar $]$. No entanto, houve um número maior de monotongações. Recorremos ao contexto alternativo para explicar esse fato. Observamos que as monotongações nesse monossílabo ocorreram todas diante de palavras que iniciam com vogal. O contexto vocálico, por sua vez, foi predominantemente o contexto de vogal alta anterior $[\mathrm{i}, \tilde{1}]$. Vejamos os números:

a) diante da vogal [a] - uma monotongação;

b) diante da vogal [e] - uma monotongação;

c) diante da vogal [ẽ] - duas monotongações;

d) diante da vogal [i] - três monotongações;

e) diante da vogal [i] - oito monotongações.

O que podemos concluir, a partir desses dados, é que o apagamento da semivogal registrado nas transcrições fonéticas nos monossílabos é diferente da monotongação nos outros contextos, porque, na maior parte dos casos, o monossílabo é seguido de uma vogal homorgânica à semivogal. Temos, então, algo como o sândi. Bisol (1992) chama esses casos de degeminação, nos quais ocorre uma ressilabação devido à fusão das duas vogais homorgânicas. Segundo a autora, não ocorre apagamento, logo não é possível dizer que a semivogal foi suprimida e fica difícil de estabelecer se o segmento com características de [i] pertence ao ditongo ou à palavra seguinte. Além disso, há de se considerar a gradiência do fenômeno e a possibilidade de formas intermediárias, tais como, [varske'ser] ou [vaiske'ser], ou, ainda, algo como [vaiske'ser], em que temos algum resquício da semivogal, seguido da vogal. Essas formas podem estar atreladas ao ritmo de fala e à taxa de elocução e uma análise acústica acurada pode mostrar evidências dessa gradiência.

No caso da vogal [î], que foi o contexto em que aconteceu a maior parte das monotongações, temos dois chunks (agrupamento de palavras que são usadas como uma unidade) responsáveis pelo fenômeno - vai indo e vai embora. Estamos diante da mesma situação que tínhamos para a vogal [i]: o ditongo, de fato, deixa de existir? Em vai embora, por exemplo, poderíamos ter ainda o ditongo, no entanto, nasalizado [vãก̊’bora].

Considerando essas ocorrências com os monossílabos descritas acima como um fenômeno à parte e os poucos casos de monotongação na palavra maior, podemos afirmar que as monotongações no ditongo [aI], em sílabas abertas, ocorrem quase que exclusivamente quando este for seguido de fricativa palato-alveolar, sendo o ditongo preservado nos demais contextos.

Tendo em vista esses resultados e o princípio de que as demais variáveis estruturais estão condicionadas ao comportamento dos itens lexicais, temos as seguintes considerações sobre a monotongação do ditongo [ar]: os monossílabos são desfavorecedores e o número de ocorrência de itens lexicais com contexto propício (fricativa palato-alveolar) vai conduzir o resultado para a variável 'número de sílabas'; o status morfológico favorável é o radical, uma vez que as sílabas seguidas pela fricativa palato-alveolar pertencem ao radical da palavra; a relação da monotongação com a variável tonicidade é significativa, no sentido de as sílabas átonas serem favorecedoras, uma vez que os monossílabos foram classificados como tônicos e a maior parte dos ditongos em radicais serem átonos (HAUPT, 2014). 
Para tratar da monotongação em sílabas fechadas, que ocorreu em maiores proporções que em sílabas abertas, fazemos a análise do contexto alternativo, isto é, aquele que inicia a palavra seguinte, e das características da fricativa final. A análise das diferentes realizações da fricativa final faz-se necessária, para verificar se há a interferência de outro fenômeno comum em Florianópolis: a palatalização da fricativa final (BRESCANCINI, 1996, 2003). Além dos estudos sobre palatalização, essa autora também realizou um estudo acerca do fenômeno de monotongação em sílabas fechadas. Segundo a autora, houve concentração de monotongação em itens específicos, a saber, mais, depois, dois e seis, e, recorrentemente, diante da realização palato-alveolar da fricativa final (houve apenas 10 ocorrências de monotongação diante de fricativa alveolar). A fim de verificar qual o comportamento do mesmo fenômeno em nossos dados, apresentamos a Tabela 3, na qual mostramos a relação entre as variáveis monotongação e fricativa final (com todas as realizações encontradas no corpus). Encontramos um resultado que aponta para um valor de $p$ baixo, confirmando a significância da relação entre os dois fenômenos, ou seja, palatalização e monotongação estão inter-relacionadas.

Tabela 3: Monotongações do ditongo [ar] em sílabas fechadas distribuídas de acordo com a realização da fricativa final

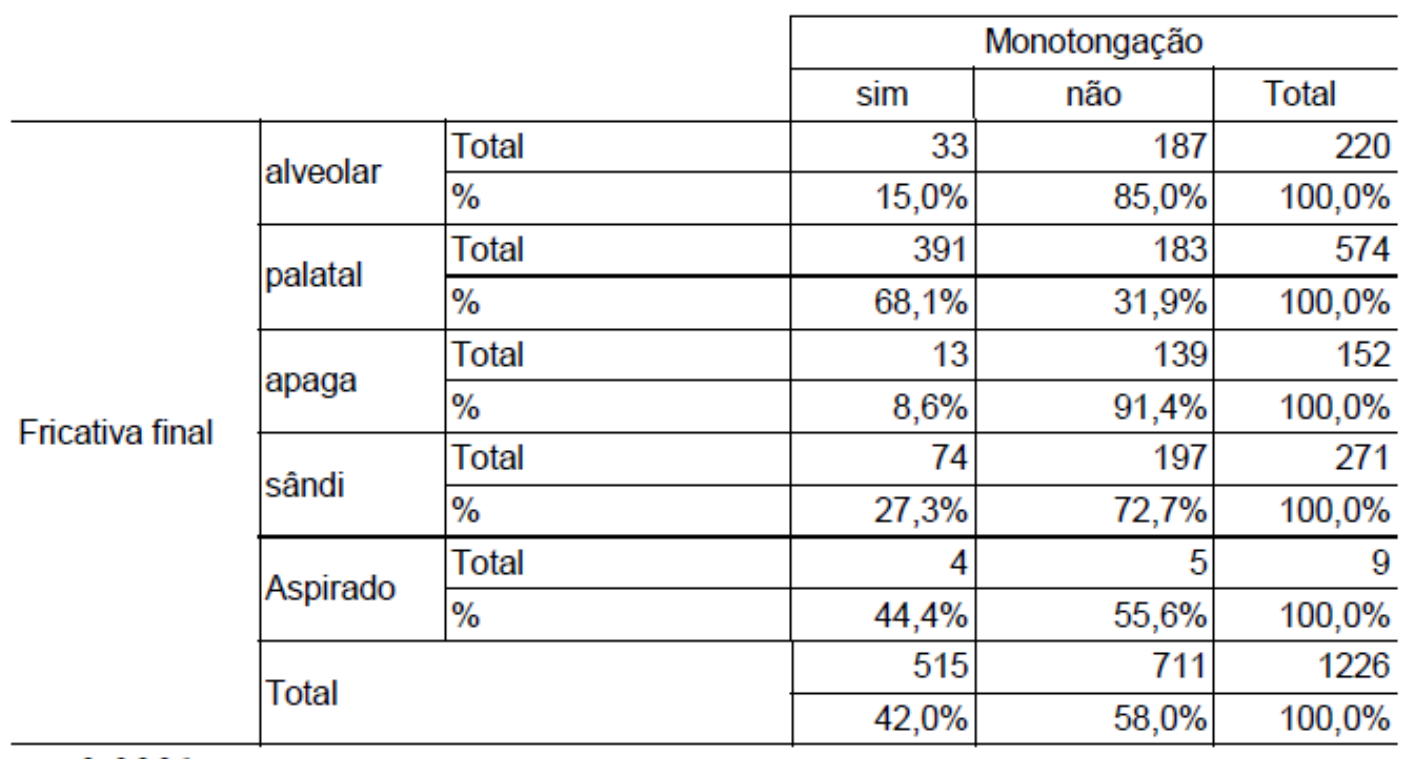

$\mathrm{p}<0,0001$

Confirmada a relação entre esses dois fenômenos em nossos dados, passamos a averiguar se os contextos alternativos em que ocorre a palatalização da fricativa final são os mesmos em que ocorre a monotongação. Para tanto, iniciamos apresentando a tabela 4 . 
Tabela 4:Monotongações do ditongo [ar] em sílabas fechadas distribuídas de acordo com o contexto alternativo

\begin{tabular}{|c|c|c|c|c|c|}
\hline & & & & otongação & \\
\hline & & & Sim & Não & Total \\
\hline & Nogol & Total & 103 & 256 & 359 \\
\hline & voyai & $\%$ & $28,7 \%$ & $71,3 \%$ & $100,0 \%$ \\
\hline & lateral & Total & 8 & 11 & 19 \\
\hline & 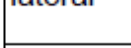 & $\%$ & $42,1 \%$ & $57,9 \%$ & $100,0 \%$ \\
\hline & Inacol & Total & 58 & 107 & 165 \\
\hline & Ilasal & $\%$ & $35,2 \%$ & $64,8 \%$ & $100,0 \%$ \\
\hline Contexto seguinte & fricativa & Total & 96 & 122 & 218 \\
\hline 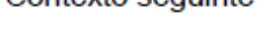 & Hincativa & $\%$ & $44,0 \%$ & $56,0 \%$ & $100,0 \%$ \\
\hline & oclusiva & Total & 197 & 157 & 354 \\
\hline & octusiva & $\%$ & $55,6 \%$ & $44,4 \%$ & $100,0 \%$ \\
\hline & nauca & Total & 53 & 58 & 111 \\
\hline & pansa & $\%$ & $47,7 \%$ & $52,3 \%$ & $100,0 \%$ \\
\hline & Total. & & 515 & 711 & 1226 \\
\hline & 10 & & $42,0 \%$ & $58,0 \%$ & $100,0 \%$ \\
\hline
\end{tabular}

$\mathrm{p}<0,0001$

Na Tabela 4, observamos que o contexto que mais favorece a monotongação é o contexto de consoante oclusiva, seguido do contexto de pausa, da consoante fricativa e de consoante lateral, essa última com poucas ocorrências. Para verificar se esses contextos também estão relacionados à palatalização, apresentamos o Gráfico 1. Nele mostramos a realização da fricativa final dos ditongos em sílabas fechadas (alveolar, palatal, aspirada, além dos casos de sândi, de apagamento) e cruzamos com o contexto alternativo. 

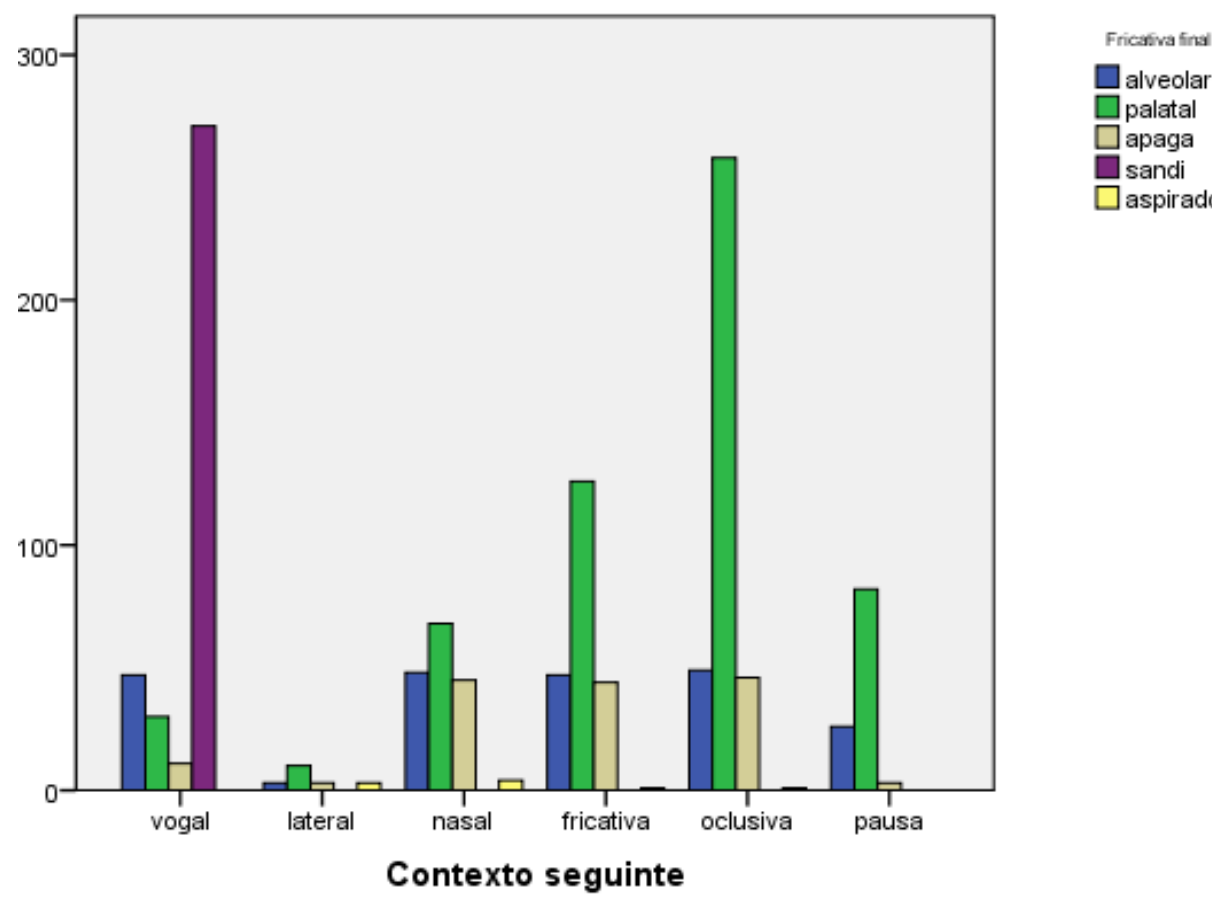

Gráfico 1: Cruzamento das variáveis 'contexto seguinte', no eixo horizontal e 'fricativa final', no eixo vertical.

Das 1.226 ocorrências de ditongo fechado, tivemos 576 casos de palatalização da fricativa final. Vemos que os contextos em que ocorre maior número de palatalização são também os contextos em que ocorre maior número de monotongações: oclusiva, fricativa e pausa. Assim, concluímos que esses contextos alternativos favorecem a monotongação, porque favorecem também a palatalização, ou seja, os contextos em que há mais monotongações são os contextos em que há mais tendência de palatalização. A palatalização da fricativa final, por sua vez, é um fator condicionante para a monotongação.

Fazendo uma análise mais minuciosa, a partir da comparação de monotongações e palatalizações em cada item lexical, observamos que, para as palavras em que houve um maior número de monotongações, houve também um maior número de palatalizações da fricativa final, inclusive para as palavras pouco frequentes que monotongaram. Dessa forma, acreditamos que acontece a expansão da generalização que ocorre nas sílabas abertas, isto é, quando o ditongo é seguido de fricativa palatoalveolar e a há monotongação em quase $100 \%$ das ocorrências, independentemente da frequência de ocorrência. Isso significa dizer que esse fenômeno está se expandindo para as sílabas fechadas, pelo fato de a palatalização criar o mesmo contexto fonético seguinte encontrado nas sílabas abertas. Em decorrência disso, concluímos que a fricativa final palatalizada constitui-se de um contexto uniforme propício para a monotongação. Como a fricativa final palatalizada é bastante frequente (576 ocorrências, equivalente a 46,8\%), explica-se por que ocorrem tantas monotongações para as sílabas fechadas.

Uma vez constatado que temos contexto fonético propício para a monotongação, esperamos que ela atinja em maiores proporções as palavras mais frequentes. Na Tabela 5, apresentamos os casos de monotongação distribuídos de acordo com a frequência de 
ocorrência dos itens lexicais com ditongo [aI ] em sílabas fechadas.

Tabela 5: Monotongações do ditongo [ar] em sílabas fechadas distribuídas de acordo com a frequência de ocorrência

\begin{tabular}{|c|c|c|c|c|c|}
\hline & & & \multicolumn{3}{|c|}{ Monotongação } \\
\hline & & & sim & não & Total \\
\hline \multirow{8}{*}{ Frequência } & \multirow{2}{*}{ alta } & Total & 452 & 569 & 1.021 \\
\hline & & $\%$ & $44,3 \%$ & $55,7 \%$ & $100,0 \%$ \\
\hline & \multirow{2}{*}{ moderada } & Total & 39 & 91 & 130 \\
\hline & & $\%$ & $30,0 \%$ & $70,0 \%$ & $100,0 \%$ \\
\hline & \multirow{2}{*}{ baixa } & Total & 24 & 51 & 75 \\
\hline & & $\%$ & $32,0 \%$ & $68,0 \%$ & $100,0 \%$ \\
\hline & \multirow{2}{*}{\multicolumn{2}{|c|}{ Total }} & 515 & 711 & 1.226 \\
\hline & & & $42,0 \%$ & $58,0 \%$ & $100,0 \%$ \\
\hline
\end{tabular}

$\mathrm{p}=0,0016$

A Tabela 5 nos mostra que há mais casos de monotongação nas palavras de alta frequência de ocorrência do que nas demais. $\mathrm{O}$ teste aponta para significância entre a frequência e a monotongação. Os itens lexicais frequentes referem-se somente à palavra mais. As ocorrências dessa palavra equivalem a 83,3\% desse ditongo em sílabas fechadas. No grupo das palavras com frequência de ocorrência moderada, estão as palavras demais, pais, vais e cais. Como pouco frequentes, encontram-se a palavra jamais e as palavras cujo ditongo faz parte da desinência de plural.

A partir do pressuposto de que as generalizações são expressas como relações entre formas, baseadas nas similaridades fonéticas e/ou semânticas, consideramos a similaridade entre as palavras jamais e demais, que também tiveram várias ocorrências de monotongação $(58,3 \%)$. Assim, para averiguar o efeito da similaridade fonética dessas formas, fizemos um reagrupamento dos ditongos em sílabas fechadas: somamos as palavras que contêm a sequência mais (demais, jamais e mais) e separamo-las das demais. Apresentamos esses novos números na Tabela 6. Observamos que o primeiro grupo tem uma frequência de ocorrência bastante alta e uma maior proporção de monotongações. Desse modo, temos uma sequência fonética ['maIs]] com alta frequência de ocorrência, na qual o fenômeno de monotongação é mais recorrente, confirmando a nossa hipótese.

Tabela 6:Monotongações do ditongo [ar] na sequência mais e demais sílabas fechadas

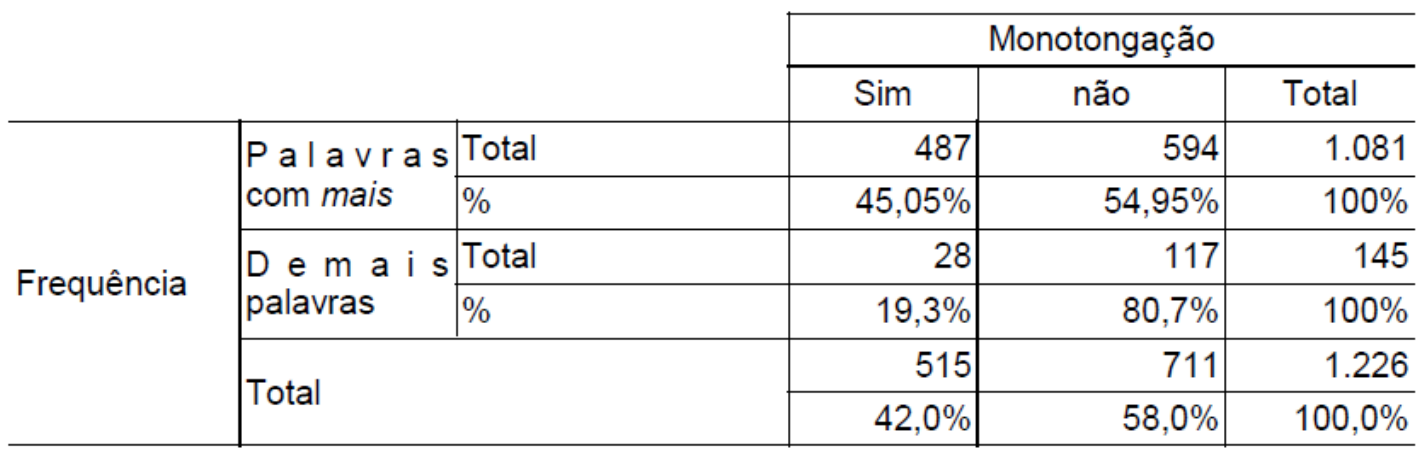

$\mathrm{p}<0,0001$ 
A partir da constatação de que a monotongação em sílabas fechadas para o ditongo [aIn] está associada à alta frequência da palavra mais e das palavras com essa sequência, fatores estruturais, tais como, tonicidade, extensão do vocábulo, etc., estarão associados às características desses itens lexicais. Os resultados no cruzamento das diversas variáveis comprovam isso: o qui-quadrado evidencia significância entre o status morfológico e a monotongação, uma vez que, em mais, jamais e demais, o ditongo [ar ] pertence ao radical; a relação entre monotongação e número de sílabas acaba não sendo significativa, pois temos o monossílabo mais, os dissílabos jamais e demais, que monotongaram, e, em contrapartida, temos o monossílabo pais $^{2}$ com poucos casos de monotongação; avaliar a tonicidade e a posição da sílaba na palavra não se faz necessário, pois todos os ditongos [arr] em sílabas fechadas são tônicos e encontram-se em sílaba no final de palavra.

Concluímos esta seção, retomando as nossas hipóteses. Acerca dos efeitos da frequência de ocorrência, confirmamos a hipótese em relação às sílabas fechadas, isto é, as monotongações atingem em maiores proporções as palavras mais frequentes. Também verificamos que os contextos alternativos (seguintes à consoante que trava as sílabas fechadas) em que mais ocorrem monotongações são aqueles que favorecem a palatalização, fenômeno que, por sua vez, propicia contexto uniforme adequado para a monotongação, decorrente da extensão da generalização da monotongação em sílabas abertas em contexto de fricativa palato-alveolar. Em sílabas abertas, não conseguimos mais visualizar os efeitos de frequência, uma vez que o fenômeno já está amplamente difundido, atingindo todos os itens lexicais com contexto uniforme propício. A hipótese em relação ao contexto alternativo, considerado nos ditongos em sílabas finais, não se confirma, uma vez que os poucos casos de monotongação ocorreram diante de vogal. Também verificamos que a alta frequência de ocorrência pode fortalecer os ditongos em alguns itens lexicais, tais como em pai, praia e vai. Por outro lado, monotongações em contextos não esperados, como na palavra maior, nos faz considerar a atonicidade da sílaba em que se encontra o ditongo na palavra maior como condição fonética suficiente para a redução.

\section{A GRADIÊNCIA DO FENÔMENO}

Nesta seção, apresentamos as análises acústicas feitas para verificar a gradiência do fenômeno pesquisado. Lembramos que fizemos o levantamento quantitativo das monotongações a partir das transcrições já feitas do VARSUL. Nas análises a seguir, pretendemos verificar se há resquícios da semivogal que não foi percebida apenas auditivamente. Partimos do pressuposto defendido pela Fonologia de Uso e da Teoria dos Exemplares de que os fenômenos não são categóricos, havendo a possibilidade de formas intermediárias entre um ditongo e monotongo. Dividimos este seção em duas partes: uma para tratar da duração e outra, da frequência dos formantes. Para essas

\footnotetext{
${ }^{2}$ Em relação à palavra pais, que teve frequência de ocorrência moderada e apenas 7 monotongações $(9,34 \%)$, podemos estabelecer uma relação com o que acontece com essa palavra no singular. Pai teve apenas uma monotongação num total de 306 ocorrências. Isso mostra que a nuvem de exemplares com a semivogal é bastante forte, o que se reflete na forma plural, mesmo que esta possa apresentar características fonéticas similares a mais, por exemplo.
} 
análises, foram selecionadas as quatro entrevistas com melhor qualidade acústica, todas de informantes do sexo masculino.

\subsection{A duração}

Embora perceptualmente a semivogal não seja mais percebida, ela pode deixar vestígios. Um possível vestígio é o alongamento da vogal, fenômeno que já foi constatado em Cristófaro-Silva, Almeida e Guedri (2007), por exemplo, ao estudar o apagamento da marca de plural, e em Cristofolini (2010) em sua investigação sobre os ditongos. Para verificar se houve essa compensação, o alongamento da vogal [a], comparamos a duração relativa de três tipos de segmentos: ditongo, vogal resultante da monotongação (ditongo monotongado) e vogal simples.

Para que a comparação seja mais precisa, consideramos contextos fonéticos semelhantes. Assim, apresentamos, na Tabela 7, as médias dos segmentos apenas em posição tônica, já que os casos de ditongos em posição átona, nas entrevistas em questão, resumem-se a duas ocorrências: à palavra caipirinha, que não monotongou, e à palavra baixava, que monotongou. Ainda a despeito da semelhança dos contextos, consideramos separadamente os contextos que antecedem o ditongo e a vogal, dividindo-os em surdos e sonoros, uma vez que as consoantes surdas são mais longas que as consoantes sonoras, o que parece interferir na duração relativa dos segmentos vocálicos em análise ${ }^{3}$. Nessa tabela, consideramos somente os ditongos em sílabas abertas.

Tabela 7: Média da duração relativa (\%) do ditongo [ar] em sílabas abertas e em contexto tônico

\begin{tabular}{l|c|c|c}
\hline Contexto tônico & Ditongo [ar $]$ & Monotongado & Vogal simples [a] \\
\hline Precedido de consoante surda & 54,5 & 57 & 46,5 \\
\hline Precedido de consoante sonora & 61,8 & 59,2 & 57,1 \\
\hline
\end{tabular}

Nesses contextos, temos as palavras pai, sai, vai, bairro, baixa, embaixo e caixa. A monotongação aconteceu em todas as ocorrências das palavras caixa, baixa e embaixo. É possível perceber que os ditongos são mais longos do que as vogais simples, o que é esperado, uma vez que aqueles envolvem dois alvos vocálicos. Já os ditongos percebidos como monotongados, que teriam o seu segundo alvo apagado, são mais extensos do que a vogal simples, o que é um indício de que há uma compensação, ou seja, apaga-se um segmento, mas alonga-se a vogal.

No caso do contexto de consoante surda precedente, a média de duração relativa do segmento resultante do apagamento da semivogal é mais longa que a do próprio ditongo. No entanto, fazemos a ressalva de que só encontramos duas ocorrências nesse contexto. Em contexto de consoante sonora, observamos que há uma gradiência, isto é, o ditongo preservado é o mais longo dos segmentos, o monotongado é mais longo do

\footnotetext{
${ }^{3}$ Já foi constatado, em diversas línguas, que as vogais são mais curtas diante de oclusivas sonoras e mais longas diante das surdas (KEATING, 1984).
} 
que a vogal simples, porém é mais curto do que o ditongo preservado; e a vogal simples é o segmento mais curto. $\mathrm{O}$ que podemos deduzir disso é que o apagamento da semivogal resulta em um segmento distinto, com evidência de gradiência, pois é mais curto que o ditongo e mais longo que a vogal.

Com as sílabas fechadas, é possível fazer a comparação tomando contextos idênticos de ocorrência dos ditongos. Isso é possível graças à alta ocorrência da palavra mais que teve várias ocorrências de monotongação ao lado de ocorrências com a preservação do ditongo. Além dessa palavra, tivemos as palavras jamais e demais, também precedidas de consoantes nasais e tônicas. Ainda temos, na lista dos ditongos em sílabas fechadas, algumas palavras no plural, tais como jornais e animais, que são incluídas nas médias abaixo. Em vista dessa peculiaridade, restringimos a ocorrência da vogal simples [a] à sílaba [ma] tônica ${ }^{4}$.

Tabela 8: Média da duração relativa (\%) do ditongo [arı] em sílabas fechadas e tônicas

\begin{tabular}{l|c|c|c}
\hline Contexto tônico & Ditongo [ar] & Monotongado & Vogal simples [a] \\
\hline Precedido de consoante nasal & 57,7 & 56,7 & 42,5 \\
\hline
\end{tabular}

Constatamos que a média de duração do ditongo e do monotongo é bastante próxima. Novamente, vemos que a duração relativa desses segmentos monotongados é superior à da vogal simples. Isso evidencia que a monotongação dessas palavras não resulta num monotongo igual à vogal simples. Pode haver um alongamento do primeiro alvo, ou ainda a presença de vestígios da semivogal, questão que averiguaremos quando tratarmos dos formantes.

O teste estatístico Anova nos mostrou que a diferença entre as médias dos ditongos preservados, dos monotongados e das vogais em sílabas abertas não foi significativa. Já, nas sílabas fechadas (que envolve um grande número da palavra mais), houve significância. $\mathrm{O}$ teste de Tukey revelou que a relação de significância se dá entre os ditongos preservados e as vogais, e os ditongos monotongados e as vogais. Entre o grupo dos ditongos e dos monotongos não há diferença significativa. Isso indica, de fato, que há o alongamento da vogal no fenômeno da monotongação. Esse alongamento, conforme o teste estatístico, é mais evidente em sílabas fechadas do que em sílabas abertas, já que nas sílabas abertas as diferenças não foram estatisticamente relevantes.

\section{a. A formação formântica}

O ditongo [ar] tem, como primeiro alvo, uma vogal baixa central e, como segundo alvo, uma semivogal alta anterior. Considerando que as vogais baixas têm F1 alto e as altas têm um F1 baixo e ainda que as vogais baixas centrais têm F2 baixo e as altas anteriores $\mathrm{F} 2$ alto, o trajeto que os formantes fariam de um alvo a outro resultaria em um movimento, no qual a trajetória de F1 é descendente, enquanto que as de F2 e F3

\footnotetext{
${ }^{4}$ Não consideramos a fricativa final na medição das sílabas com os ditongos para que pudéssemos comparar com a vogal, cujas ocorrências predominantemente são em sílabas abertas.
} 
são ascendentes. Lembramos que o terceiro formante tende a acompanhar a trajetória de F2 e pode ser afetado pelo arredondamento dos lábios, sendo mais alto para as vogais não arredondadas. Começamos analisando os ditongos em sílabas abertas, em palavras, como baixo e caixa.

Já constatamos, na Seção 3.1, que a duração de um ditongo monotongado nesse contexto não é a mesma de uma vogal simples. Para ver o comportamento dos formantes, sobrepomos os formantes de uma vogal simples, de um ditongo preservado 5 e de vários monotongados, a partir de seis pontos distintos. Os três pontos iniciais foram retirados da parte inicial dos segmentos, enquanto os três últimos, da parte final. Dessa maneira, os três primeiros pontos estão relacionados ao primeiro alvo, a vogal [a], enquanto os três últimos, ao segundo alvo, a semivogal [I]. Tomamos o cuidado de não incluir a coarticulação dos segmentos adjacentes e a transição (quando havia). $\mathrm{O}$ Gráfico 2 refere-se ao F1 e o Gráfico 3, ao F2.

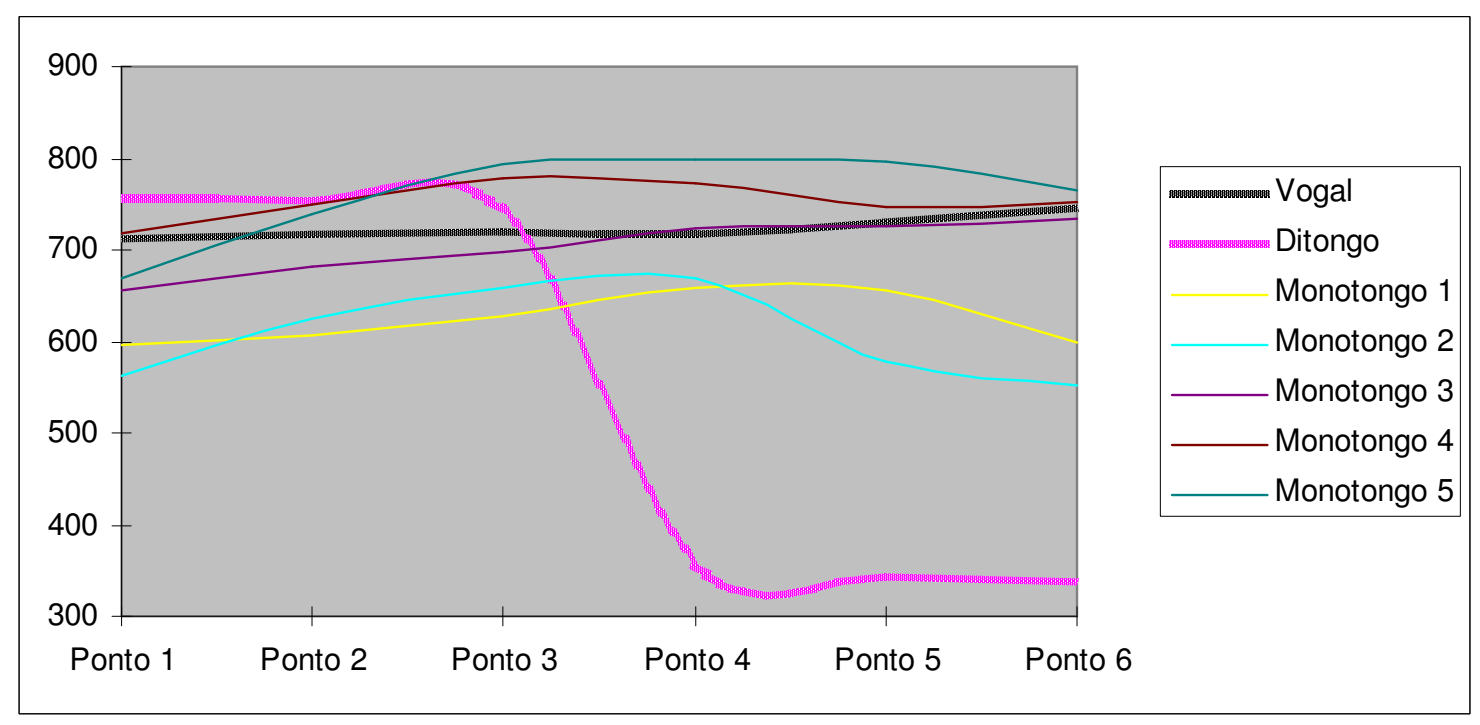

Gráfico 2: Seis pontos de F1 de um ditongo [ar], da vogal [a] e de ditongos monotongados em sílabas abertas ${ }^{6}$.

\footnotetext{
${ }^{5}$ Esse ditongo foi retirado de uma gravação de fala controlada, em que o informante repetia uma lista de palavras com ditongos. Fizemos isso justamente com a intenção de apresentar um ditongo com alvos e transição indiscutíveis. Trata-se, também, de um informante masculino.

${ }^{6}$ Reduzimos a escala de visualização de alguns gráficos para melhor podermos analisar o caminho dos formantes no decorrer dos seis pontos.
} 


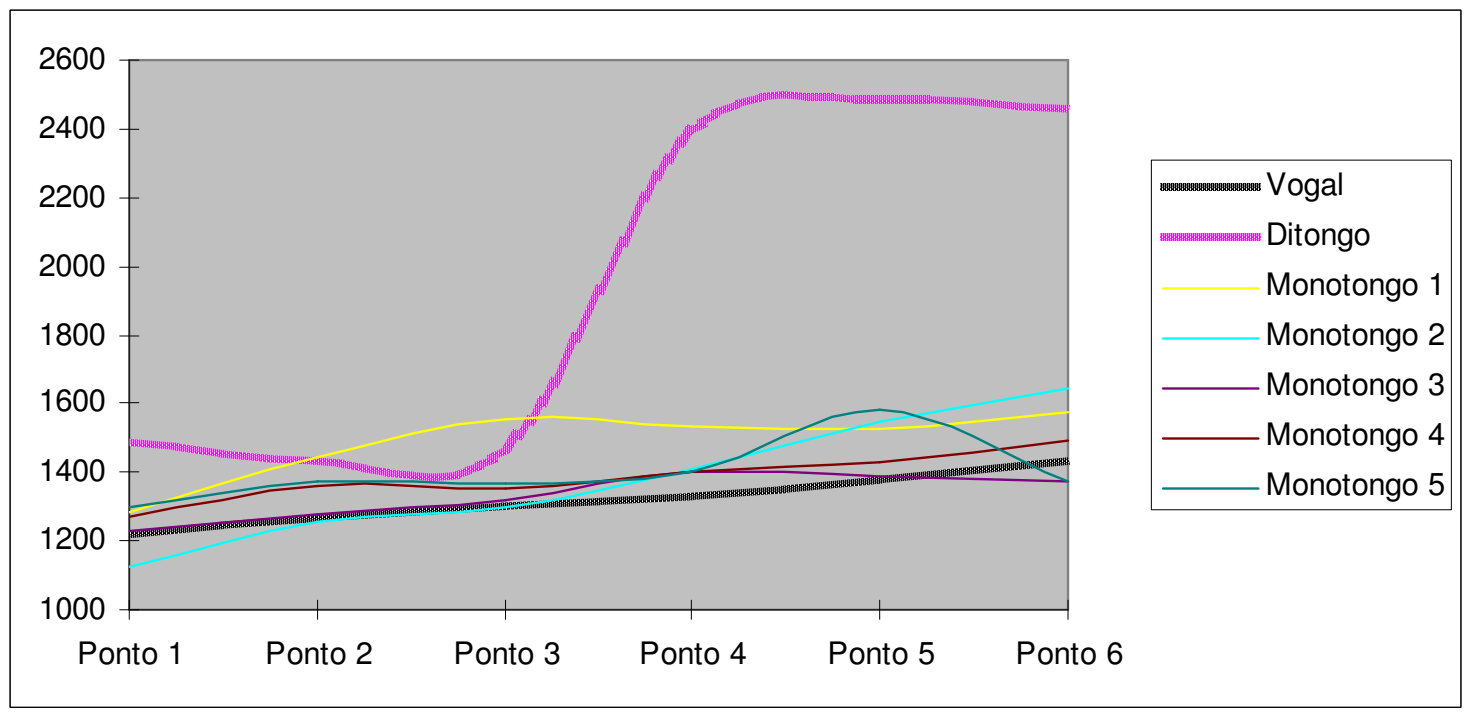

Gráfico 3: Seis pontos de F2 de um ditongo [ar], da vogal [a] e de ditongos monotongados em sílabas abertas.

A linha mais densa preta refere-se à vogal simples e a linha mais densa rosa, ao ditongo preservado. As demais linhas são ditongos que foram percebidos como monotongos nos dados do VARSUL. Podemos observar, pelos Gráficos 2 e 3, que a trajetória formântica da vogal é estável, ou seja, os dois primeiros formantes mantêm-se com valores próximos, enquanto, no ditongo preservado, o F1 desce e o F2 sobe, evidenciando a presença de dois alvos com características formânticas distintas, caracterizando, como segundo alvo vocálico, um segmento alto anterior, a semivogal [I]. Além disso, temos também uma região de transição evidente entre os dois alvos, confirmando que de fato temos um ditongo. Nos ditongos monotongados, os valores frequenciais aproximam-se daqueles exibidos pela vogal simples. Contudo, observamos que, para os monotongados 1 e 2 , há um declive nos dois últimos pontos relativos ao F1, o que pode indicar a articulação inicial de uma vogal mais alta que não se completa. Os monotongados 4 e 5 também apresentam uma queda, porém inferior, ficando próximos aos pontos da vogal simples. Observando agora o Gráfico 3, visualizamos o mesmo comportamento para $\mathrm{F} 2$, isto é, os seis pontos dos monotongos são próximos aos da vogal, porém os monotongados 1 e 2 fazem uma trajetória alternativa que eleva um pouco seus valores, se comparados aos demais, parecendo ratificar um provável início de articulação do segundo alvo que não se completa.

Ao realizarmos o teste Anova, tivemos resultados diferentes para F1 e o F2: para o primeiro formante, as diferenças entre os valores referentes ao primeiro alvo não foram significativamente distintas dos valores dos três últimos pontos. Já para o F2, essa relação foi significativa $(\mathrm{p}=0,000214)$.

Realizamos o mesmo procedimento com os ditongos fechados, especificamente com as palavras mais e demais (Gráfico 4). Olhando para os valores de cada ponto, observamos uma maior variabilidade. Há, em alguns dos monotongados, como nos exemplos 1, 4 e 5, mais oscilação nos valores dos diferentes pontos. No entanto, os valores são ainda superiores aos da semivogal [I] para F1. O teste Anova não revelou significância entre os valores dos três pontos iniciais e dos três pontos finais. Isso indica 
que os valores desses formantes parecem mais próximos aos valores da vogal [a].

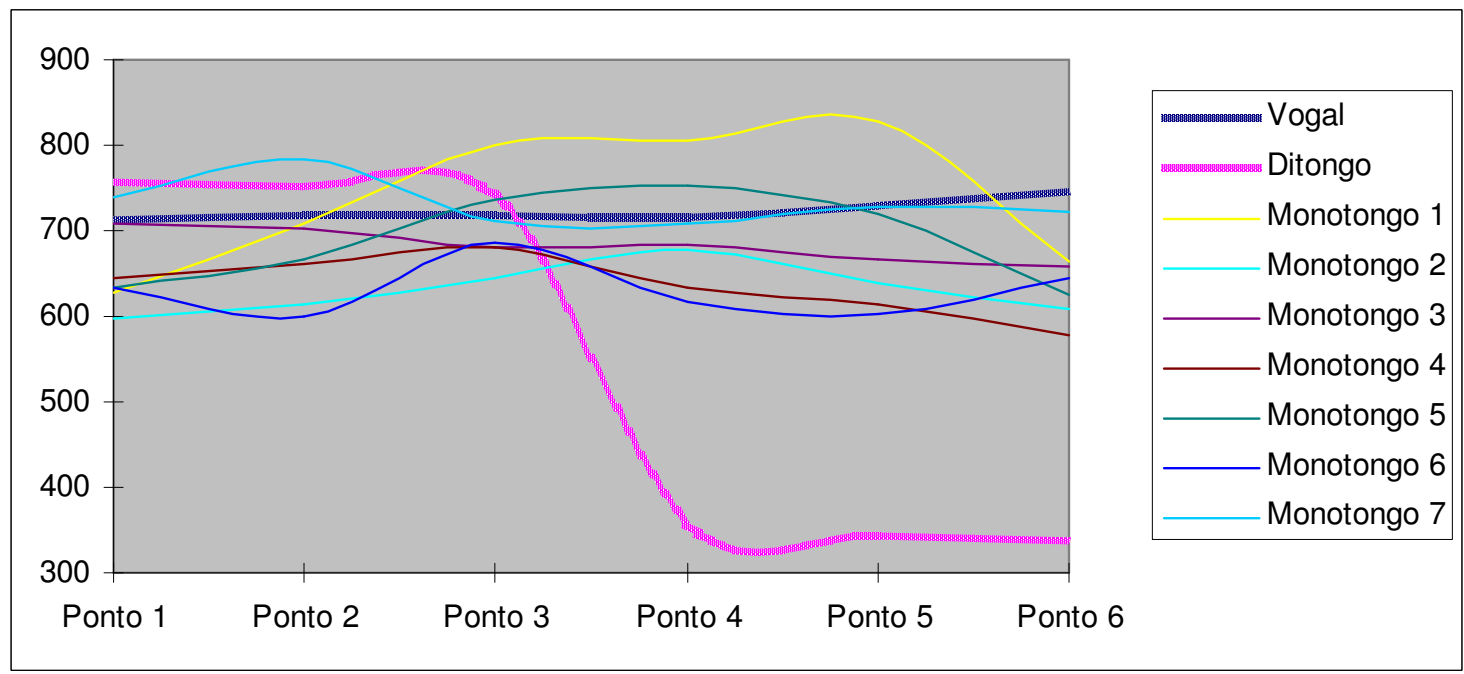

Gráfico 4: Seis pontos de F1 de um ditongo [aI], da vogal [a] e de ditongos monotongados em sílaba fechada.

O Gráfico 5 refere-se aos valores de F2. O teste Anova atestou que a diferença entre os valores de iniciais e finais é significativa para os ditongos monotongados nesse formante. Percebemos, então, que há uma elevação dos valores para alguns dos ditongos monotongados, por exemplo, para o monotongado 1 , o 3 e o 6 . A elevação dos três pontos finais, assim como a queda no F1 poderia ser decorrência de efeitos de coarticulação. No entanto, essas alterações ocorrem principalmente nos pontos 4 e 5 e, como dissemos anteriormente, deixamos de fora das etiquetagens dos segmentos a região de coarticulação com os segmentos adjacentes. Assim, muito provavelmente essas alterações se referem aos segmentos focalizados neste estudo.

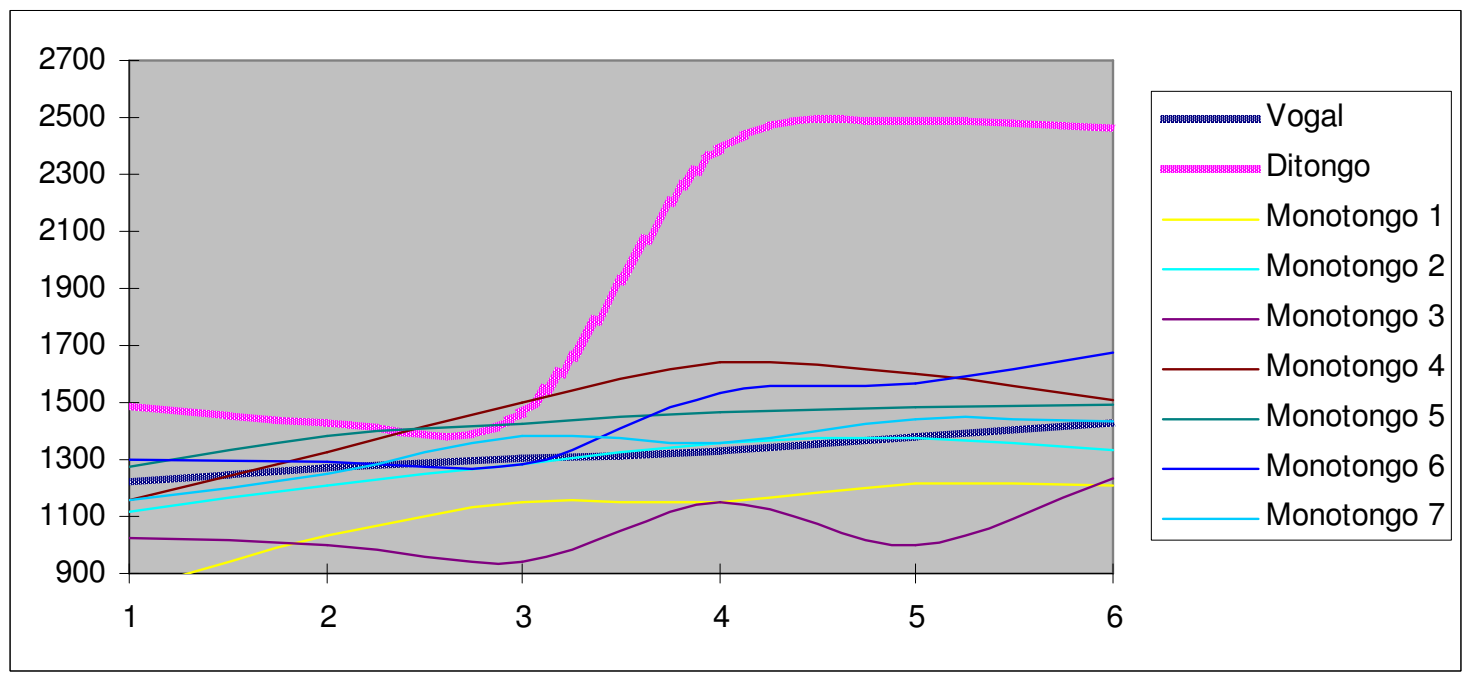

Gráfico 5: Seis pontos de F2 de um ditongo [aI], da vogal [a] e de ditongos monotongados em sílaba fechada. 
Dessa forma, podemos concluir que a monotongação do ditongo [ar], tanto em sílabas abertas quanto fechadas, tem sua gradiência evidenciada não apenas pela duração, ou seja, pelo alongamento do primeiro alvo ao se apagar a semivogal, mas também pela presença de traços formânticos que caracterizam o início da articulação do segundo alvo vocálico [I] , com diferenças significativas para F2. Quando isso não ocorre, temos a variante que apresenta apenas um alongamento da vogal núcleo do ditongo.

Para finalizar a discussão sobre o ditongo [ar $]$, apresentamos ainda algumas produções que foram percebidas como ditongos em sílabas fechadas, a fim de verificar se é possível encontrar configurações intermediárias também nesses segmentos. Os Gráficos 6 e 7 mostram a trajetória de F1 e F2, respectivamente.

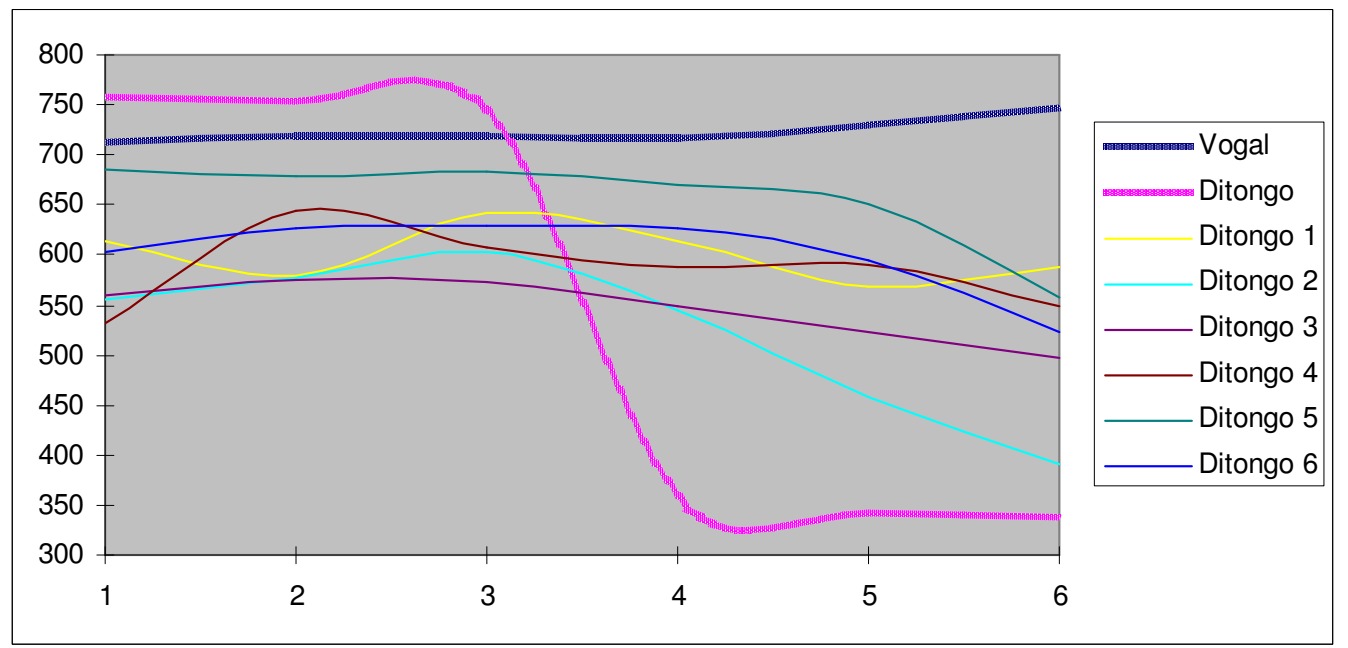

Gráfico 6: Seis pontos de F1 de um ditongo [ar], da vogal [a] e de exemplares da palavra mais com ditongo preservado.

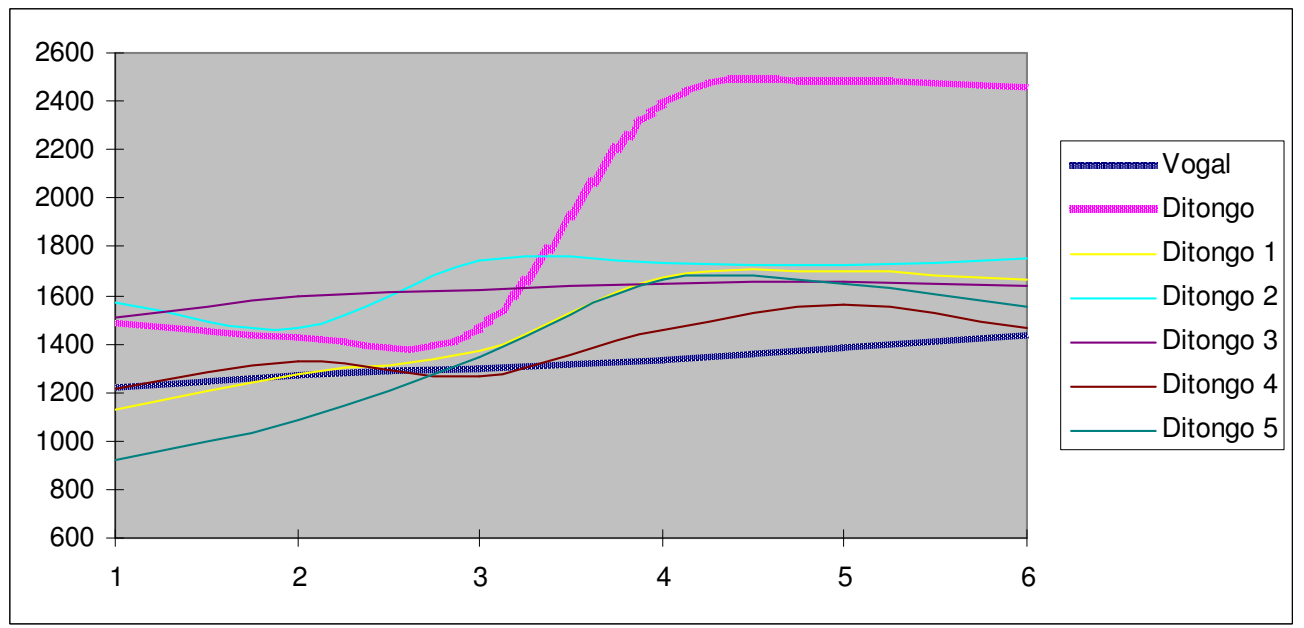

Gráfico 7:Seis pontos de F2 de um ditongo [ar], da vogal [a] e de exemplares da palavra mais com ditongo preservado.

Vemos que esses ditongos preservados exibem trajetórias distintas dos monotongados apresentados nos gráficos anteriores. Percebemos que tanto os valores de 
F1 quanto os de F2 apresentam movimentação dos três pontos iniciais para os três finais, embora os finais ainda não atinjam os valores da semivogal [I]. Esse resultado corrobora os estudos feitos por Dias e Machado (2001), nos quais os autores atestam que os formantes da semivogal são menos estáveis, apresentando maiores variações de frequência. Assim, temos, para F1, um declínio que, no entanto, não se estabiliza. Para F2, é possível visualizarmos uma região estável que caracterizaria o segundo alvo, porém com valores bem inferiores aos exibidos pelo ditongo obtido com condições controladas de gravação ${ }^{7}$.

Outra diferença entre os ditongos preservados e os monotongados, refere-se à transição entre os dois alvos vocálicos, percebida na trajetória de F2 em todos os ditongos preservados, com exceção do 3 (o ditongo 3 não se configura como um segmento complexo com dois alvos fonéticos distintos, nem para F1, nem para F2). De acordo com a estatística do teste Anova, as diferenças dos valores de F1 do primeiro alvo e do segundo alvo nos ditongos preservados não foram significativas ( $\mathrm{p}=0,0523)$. Todavia, o valor de $p$ está bem próximo da margem de erro adotada nesse trabalho $(0,05)$. Já para $\mathrm{F} 2$, tivemos $\mathrm{p}<0,0001$.

Embora possamos identificar essas diferenças entre as formas monotongadas e os ditongos preservados, e até significância entre as diferenças dos valores do primeiro e segundo alvo para F2, observamos pelos gráficos que, em condições normais de fala, os ditongos preservados nem sempre apresentam dois alvos estáveis para os dois formantes e uma região de transição. Desse modo, podemos afirmar que, também para um ditongo percebido como tal, temos formas intermediárias, que podem já ser um indício de redução do ditongo, constituindo-se, assim, em mais uma evidência de gradiência do fenômeno da monotongação.

\section{CONSIDERAÇÕES FINAIS}

Nesse trabalho, buscamos contribuir para a discussão sobre o fenômeno da monotongação do ditongo [aI ] na fala dos florianopolitanos, considerando a Fonologia de Uso e seu modelo representacional, a Teoria dos Exemplares. Observamos que a monotongação desse ditongo em sílabas abertas se dá preferencialmente em contextos de consoante seguinte palato-alveolar, em quase $100 \%$ das palavras, anulando o efeito da frequência de ocorrência. Já em sílabas fechadas, o efeito de automatização de itens com alta frequência é visível. Observamos também que, em sílabas fechadas, a monotongação ocorre preferencialmente quando ocorre também a palatalização, inclusive nos mesmos contextos alternativos. Consideramos, portanto, a fricativa palatoalveolar resultante da palatalização como contexto propício para a monotongação, assim como nas sílabas abertas. Em termos de exemplares, percebemos a expansão do monotongo nesse contexto, o que fortifica as nuvens que contemplam essa categoria. Mas não se trata de duas categorias estanques, já que a análise acústica evidencia gradiência entre a categoria de ditongo e monotongo.

À parte essas considerações, a situação da variação desse ditongo está posta, tanto em sílabas abertas quanto em sílabas fechadas, na comunidade florianopolitana. Percebemos que os efeitos da automatização decorrentes da alta frequência de

\footnotetext{
${ }^{7}$ Valores de F2 mais baixos para a semivogal [I] em comparação com os da vogal simples já foram encontrados nos estudos de Moutinho, Rua e Teixeira (2005).
} 
ocorrência reduzem o ditongo até em contextos fonéticos não propícios, como na palavra maior e no monossílabo vai. Nossas análises, portanto, nos permitem afirmar que a monotongação é de fato um fenômeno de redução. Como o fenômeno em ditongos abertos seguidos de fricativa palato-alveolar atinge em altas porcentagens todos os itens lexicais com esse contexto, um próximo passo seria fazer um estudo longitudinal e com diferentes faixas etárias para averiguar se temos uma mudança em curso.

\section{REFERÊNCIAS}

BISOL, L. Sândi vocálico externo: degeminação e elisão. Cadernos de Estudos Linguísticos. Campinas. V. 23, p. 83-101, jul./dez. 1992.

BRESCANCINI, C. A palatalização da fricativa alveolar não-morfêmica em posição de coda no português falado em três regiões de influência açoriana no município de Florianópolis.1996. 219f. Dissertação (Programa de Pós-Graduação em Linguística) Centro de Comunicação e Expressão, UFSC, Florianópolis, 1996.

A palatalização da fricativa em posição de coda no dialeto florianopolitano: variáveis linguísticas. In: HORA, D. da; COLLISCHONN, G. (Orgs). Teoria Linguística: fonologia e outros temas. João Pessoa: EditoraUniversitária, 2003. p. 291326.

A redução de ditongos decrescentes seguidos por fricativa em coda no açoriano-catarinense. In: BISOL, L.; COLLISCHONN, G. (Orgs). Português do sul do Brasil:variação fonológica. Porto Alegre: Edipucrs, 2009, p. 34-49.

BYBEE, J. The phonology of the lexicon: Evidence from lexical diffusion. In: BARLOW, M. e KEMMER, S. (Orgs) Usage-based models of language.Stanford, 2000, p. 65-85.

. Phonologyandlanguage use.Cambridge University Press, 2001.

CRISTÓFARO-SILVA, T.; ALMEIDA, L.; GUEDRI, C. Perda da marca de plural no português brasileiro: contribuições da Fonologia. Estudos linguísticos. Belo Horizonte. Vol. 15, no 2, p. 2007-228, jul./dez. 2007.

CRISTÓFARO-SILVA, T.; GRECO, A. Representações fonológicas: contribuição da oralidade e da escrita. Letras de Hoje,Porto Alegre, v.45, n.1, p. 87-93, jan./mar, 2010.

CRISTOFOLINI, C. Estudo da monotongação de [ow] no falar florianopolitano: perspectiva acústica e sociolinguística. Revista $d a$ Abralin, n.1, v.10, 2011.

DIAS, A. de S.; MACHADO, M. da M. Análise acústico-articulatória das vogais assilábicas do português do Rio de Janeiro. In: V Congresso Nacional de Lingüística e Filologia, 2001, Rio de Janeiro. Cadernos do CNLF. Rio de Janeiro: CiFEFiL, v. 06, 2001.

ELLIS, N. C. Frequencyeffects in languageprocessing. Studies in Second Language Acquisition.Cambridge University Press, n. 24, p. 143-188, jul 2002.

HAUPT, C. A palavra como lócus de análise da variação fonética-fonológica. Letras de Hoje, Porto Alegre, v. 49, n. 1, p. 36-45, jan./mar., 2014. 
JOHNSON, K. The auditory/perceptual basis for speech segmentation. OSU WorkingPapers in Linguistic.n ${ }^{\circ}$ 50, p. 101-113, 1997

MOUTINHO, L.; RUA, C.; TEIXEIRA, A. Ditongos orais no Português europeu. In: DUARTE, I.; LEIRIA, I. (org.), Actas do XX Encontro da Associação Portuguesa de Linguística, Lisboa: APL/Colibri, 2005, pp. 803-816.

PIERRENHUMBERT, J. Exemplar Dynamics: Word frequency, lenition and contrast. In BYBEE, J. \& HOPPER, P. (Orgs). Frequency and the emergence of linguistic structure.Amsterdam: Benjamins, 2000, p. 123-136.

PHILLIPS, B. Word Frequency and the Actuation of Sound Change.Language.vol 60, n 2, p 320-342, junho, 1984.

Lexical diffusion, lexical frequency and lexical analysis. In: BYBBE, J., HOPPER, P. (orgs). Frequency and the emergence of linguistic structure.John Benjamins Publishing, Co, 2001, p. 123-136.

Data de submissão: 17/07/2014

Data de aceite: 06/10/2014 